\title{
Bērna tiesības zināt savu izcelsmi: tiesību apjoms un aktuālie problēmjautājumi
}

\author{
Olga Škserberga \\ Rìgas Dome, Rìgas bārintitiesa", Latvija
}

\section{Kopsavilkums}

Informācija par izcelsmi ir būtiska personas identitātes sastāvdaḷa, tā ir viena no bērna pamattiesībām un ietilpst tiesības uz privātās dzīves aizsardzību tvērumā. Bērna tiesības zināt savu izcelsmi, tāpat kā tiesības uzaugt ğimenē vai tiesības tikt uzklausītam, ir viena no pamattiesībām, ko aizsargā starptautiskie akti. Tomēr šīs tiesības îstenošana nacionālajā līmenī pilnībā liegta bērniem, kuri ir adoptēti, dzimuši izmantojot donora dzimumšūnas, un glābējsilītē ievietotiem bērniem.

Atslēgvārdi: izcelsme, adopcija, glābējsilīte, medicīniskā apauglošana.

\section{Raksta mērḳis}

Raksta mērḳis ir atklāt tiesiskā regulējuma problēmas bērna tiesībām zināt savu izcelsmi adopcijas, glābējsilī̌u un medicīniskās apaug̣̦ošanas gadījumā, izvirzot priekšlikumus risinājumiem taisnīga līdzsvara nodrošināšanai indivīdu konkurējošu interešu aizsardzībā.

\section{Pētniecības metodes}

Izmantota vēsturiskā, deskriptīvā, analītiskā un salīdzinošā pētniecības metode. Analìtiskā metode izmantota, lai izpētìtu Latvijas un arì citu valstu nacionālos tiesību aktus, starptautiskos un reg̣ionālos tiesību avotus. Deskriptīvā (aprakstošā) metode

\footnotetext{
"Raksta autore nepauž Rīgas domes Rīgas bāriṇtiesas viedokli. Raksta pamatā ir autores maǵistra darbs "Bērna tiesības zināt savu izcelsmi: apjoms un aktuālie problēmjautājumi", kas 2014. gada 31. janvārī aizstāvēts RSU Juridiskās fakultātes maǵistra darba novērtēšanas komisijā. Mağistra darbs pilnā apjomā ar nosaukumu "Bērna tiesības zināt savu izcelsmi. Aktuālie problēmjautājumi” 2014. gada 29. septembrī izdots akadēmiskajā izdevniecībā "Globe Edit”.
} 
izmantota, lai aprakstītu jēdzienu skaidrojumus. Vēsturiskā metode tiek lietota, lai uzsvērtu, kā starptautiskā un regionālā līmenī ir attīstījušās bērnu tiesības zināt savu izcelsmi, vecākus. Salīdzinošā metode tiek izmantota, lai parādītu, kā bērna tiesības zināt vecākus tiek īstenotas citās valstīs, lai salīdzinātu un izvērtētu dažādu valstu tiesību zinātnieku atziņas, kā arī lai aizgūtu idejas nepilnību novēršanai nacionālajos tiesību aktos, ja konstatēta neatbilstība starp uzn,emtajām saistībām un bērna tiesībām zināt savu izcelsmi regulējumu Latvijas tiesību aktos.

\section{Diskusija un rezultāti}

Sabiedriskajā telpā izskanēja informācija, ka ANO Bērnu tiesību komitejas pārstāve vēlas aizliegt glābējsilïtes, jo to pastāvēšana pārkāpj bērnu tiesības zināt, kas ir viṇu vecāki, un veidot ar viṇiem personiskas attiecības. [16] Šì ziṇa autorei raisīja pārdomas par to, vai un kādā apjomā valsts atzīst un aizsargā ANO Konvencijā un ECT Konvencijā garantētās bērna pamattiesības zināt savu izcelsmi nacionālā tiesību sistēmā arī medicīniskās apauglošanas gadỉjumā, kad piekḷuve informācijai par bērna izcelsmi ir liegta donora anonimitātes aizsardzības dẹl, un adopcijas gadïjumā, kad ziņas par bērna izcelsmi liedz izpaust adopcijas noslēpums.

Bērna tiesības zināt savus vecākus ir viena no ANO 1989. gada 20. novembra Konvencijas par bērna tiesībām (turpmāk - ANO Konvencija) 7. panta pirmajā daḷā noteiktajām bērna pamattiesībām. Šìs tiesības tostarp izriet no 1950. gada 4. novembra Eiropas Cilvēktiesību un pamatbrīvību aizsardzības konvencijas (turpmāk - ECT Konvencijas) 8. panta pirmajā dạ̣ā ietvertā jēdziena "privātā dzīve" interpretēšanas. [4,5] Bērna tiesības zināt savu izcelsmi nav absolūtas. ANO Konvencijas 7. panta pirmajā daḷā ietvertā klauzula "ciktāl tas iespējams" ierobežo šo tiesību piemērošanu bez nosacījumiem, tā attiecināma uz šādiem gadījumiem:

1) ja vecāku nav iespējams identificèt;

2) ja māte atsakās izpaust bērna tēva identitāti, iekḷaujot situācijas, ja bērns ieñemts incesta vai izvarošanas rezultātā;

3) ja valsts ir izlēmusi, ka vecāki nedrīkst tikt identificēti. [13, 117]

Tomēr trešo gadījumu kategorija ietver visstrīdīgākos aspektus bērnu tiesību ierobežošanas nepieciešamībā un pamatotībā, jo klauzulas interpretācijas rezultātā dažkārt nevajadzīgi tiek pārkāptas bērna tiesības zināt savus vecākus. No Eiropas Cilvēktiesību tiesas (turpmāk - ECT) prakses atziṇām izriet, ka tiesību uz privātās un giimenes dzīves neaizskaramību ierobežojums ir attaisnojams, lai aizsargātu citu personu tiesības un brīvības, ja vien ierobežojums ir samērīgs ar sasniedzamo mērḳi. [6, 7]

Nemot vērā, ka bērna tiesības zināt savu izcelsmi izriet no starptautiskā un reǵionālā līguma, tad aplūkojot ANO un Eiropas Padomes (turpmāk - EP) nostāju, secināms, ka ANO pauž nepārprotamu nostāju nepieciešamībā nodrošināt bērnam tiesības zināt savus vecākus, iesakot novērst anonīmi atstāto bērnu praksi, kā arī nodrošināt adoptētiem un medicīniskās apaugḷošanas ceḷā dzimušiem bērniem tiesības zināt savus 
izcelsmes vecākus. [10, 11] EP savukārt atzīst, ka visiem bērniem ir likumīgas intereses attiecībā uz vinu izcelsmi, piel̦aujot, ka dalībvalstis nacionālajos tiesību aktos drīkst ierobežot vai liegt bērnam piekḷuvi informācijai par savu izcelsmi, ja šis ierobežojums atbilst bērna vai iesaistīto personu interesēm. [12] Līdz ar to šo tiesību ierobežojums vai liegums attaisnojams, izvērtējot bērna vai iesaistìto personu intereses. Absolūts bērna tiesību liegums zināt savu izcelsmi ir pretrunā starptautiskajām prasībām.

Tiesību zinātnieces Katerina Donovana un Jaijna Kothari norāda, ka bērnam ir nepieciešams darīt zināmu informāciju par savu izcelsmi psiholoğiskas nepieciešamības dẹl, vēlmes zināt savu un senču slimību vēsturi un mantojuma tiesiskās intereses dēḷ. İpaši tiek uzvērta psiholoǵiskā nepieciešamība, jo šìs informācijas trūkums bērnam var izraisìt personības attīstības problēmas. [14, 15] Jānorāda, ka tiesību zinātnieku vidū nav vienprātības par donoru identificējošas informācijas izpaušanu bērnam. Džeina Stolle, piemēram, norāda, ka, neatkarīgi no bērna izcelšanās veida, dalībvalstij ir pienākums nodrošināt, lai bērna tiesības zināt savus vecākus tiktu aizsargātas, savukārt Irina Dikova uzskata, ka dzimumšūnu donora anonimitātes aizliegšanas gadijumā strauji samazināsies dzimumšūnu donoru skaits. [17, 18]

Vērtējot nacionālo tiesību aktu atbilstību starptautiskajām prasībām, atzīstams, ka tiesību normās ir pārṇemti vadošie ANO Konvencijas tiesību principi, to skaitā tiesības būt informētam par savu izcelsmi, tomēr dažu tiesību normu interpretēšanas rezultātā tiesību normu piemērotājs var nonākt pie nepamatota bērna tiesības uz izcelsmi aizskāruma. Proti, Bērnu tiesību aizsardzības likuma (turpmāk - BTAL) 8. pants noteic, ka bērnam ir tiesības uz individualitāti, kas sevī ietver tiesības. uz savas identitātes saglabāšanu. Jēdziens identitāte likumā nav definēts, tomēr, atsaucoties uz judikatūrā izteiktām atzin̄ām, norādāms, ka "bērnu vislabākās intereses un identitātes izjūtu var saglabāt, neliedzot vinịiem iegūt zināšanas par savu izcelsmi. Ar identitātes saglabāšanu apzīmē gan neiejaukšanos identitātē, gan arī ierakstu, kas saistīti ar genealoǵiju, dzimšanas reǵistrāciju un detalizētu informāciju par bērnības agrīno posmu, ko bērns nevar atcerēties, saglabāšanu." [1]

Citā spriedumā tiesa norāda, ka "identitāte nozīmē vairāk nekā tikai zināšanas, kas ir viṇa vecāki. Brāḷi un māsas, vecvecāki un citi radinieki var būt tikpat vai vēl vairāk svarīgi bērna identitātes apzināšanai nekā tikai vecāki" un ka "koncepcija par bērna identitāti ir koncentrējusies uz bērna tuvāko gimeni”. [2] No minētā tiesas skaidrojuma izriet, ka jēdziens identitāte aptver vairākus aspektus, ar to saprotot gan neiejaukšanos identitātē, gan ierakstu saglabāšanu saistībā ar genealoǵiju un dzimšanas regiistrāciju, kā arī neliegšanu iegūt zināšanas par savu tuvāko ǵimeni, piemēram, adoptētājiem, bet no minētā neizriet, ka bērns var iegūt informāciju par savu bioloǵisko ğimeni, jo tā nav viṇa tuvākā goimene.

Bērnam, kurš atrodas ārpusğimenes aprūpē, ir tiesības būt informētam par to, kas ir viṇa vecāki, to nosaka BTAL 34. pants. Likumā nav dots skaidrojums jēdzienam vecāks, tomēr, ņemot vērā, ka bērna un vecāka personiskās tiesiskās attiecības regulē Civillikums (turpmāk - CL), un atsaucoties uz tiesas sniegtu skaidrojumu, norādāms, 
Olga Šḳerberga. Bērna tiesības zināt savu izcelsmi: tiesību apjoms un aktuālie problēmjautājumi

ka "CL izpratnē par vecākiem atzīstamas, nevis tādas personas, no kurām bērns ir cēlies, bet kurām ir likumā noteiktā kārtībā nodibināts attiecīgs statuss vai šis statuss likumā noteiktā kārtībā nav atṇemts." [3] Attiecīgi secināms, ka bērnam ir tiesības būt informētam par saviem juridiskajiem vecākiem, bet ne izcelsmes vecākiem, ja tie zaudējuši vecāka statusu. No sniegtās interpretācijas izriet, ka subjektu loks, kam šì norma ir piemērojama, kḷūst vēl mazāks, jo faktiski tikai likumā īpaši paredzētos gadījumos, bērnam atrodoties ārpusğimenes aprūpē, viṇa vecākiem netiek pārtrauktas aizgādības tiesības.

Latvijas nacionālo tiesību normas aizsargā adoptētāja tiesības uz anonimitāti un aizliedz izpaust ziṇas par adopcijas faktu jebkurām personām, to skaitā adoptētajam līdz pilngadības sasniegšanai, līdz ar to Civilstāvokḷa aktu likuma 9. panta otrajā dạ̣ā un CL 171. panta trešajā daḷā ir ievērotas EP Konvencijas par bērnu adopciju 20. panta trešajā punktā noteiktās prasības. Tomēr, vērtējot nacionālo tiesību normu atbilstību ANO Konvencijas 7. panta pirmās daḷas prasībām kopsakarā ar ANO pausto nostāju, jānorāda, ka bērnam, kurš ir adoptēts, nav nodrošinātas tiesības zināt savu izcelsmi. Šāds aizliegums adoptētajam zināt savu izcelsmi nav objektīivi pamatots un samērīgs ar sasniedzamo mērki. Autore par piemērotāko risinājumu interešu līdzsvarošanai uzskata Francijas tiesiskā regulējuma modeli.

Lielākajā dạ̦ā ANO un EP dalībvalstu, tostarp arī Latvijā, donoru anonimitāte tiek vērtēta augstāk nekā bērna tiesības zināt savu genētisko vēsturi, jo ziṇas par biologiskajiem vecākiem var ietekmēt gan neauglīgos vecākus un bērnu integrēšanos ğimenē, gan donorus. [8] Jānorāda, ka nepastāv vienots pareizs anonimitātes risinājums, jo vienlaikus saduras trīs atškirīgas intereses - domājamo vecāku un donora tiesības uz privātumu un anonimitāti un bērna tiesības zināt izcelsmi. Ne vienmēr ir iespējams vienlaikus nodrošināt šo tiesību ievērošanu, tomēr, lai īstenotu ANO un ECT Konvencijā noteiktās prasības, iespējamais risinājums būtu paredzēt kompetentai institūcijai izvērtēt, kādā apjomā šĩ informācija ir izpaužama, n̦emot vērā bērna vecumu un briedumu, nepārkāpjot dzimumšūnu donora un juridisko vecāku tiesības uz privātumu. Šāda informācija ietvertu genealoǵiska rakstura datus, ziṇas par dzimumšūnu donora tautību, slimību vēsturi u. c., bez personas identificējošu datu atklāšanas.

Glābējsilī̌su projekts sabiedriskajā telpā ir aktualizējis jautājumu par bērna izcelsmi un genealogiiska rakstura informācijas pieejamības nodrošināšanu bērnam. Glābējsilìtē atstātajam bērnam nav iespējams īstenot tiesības zināt savu izcelsmi, jo bērna vecāki nav zināmi. Tomēr, ja bērna māte izvēlēsies dzemdēt bērnu, neizpaužot savu identitāti vai uzdosies par citu personu, arī tad šo tiesību nodrošināšana nebūs iespējama, jo valsts iestāžu rīcībā nebūs ziṇu par bērna izcelsmi. No otras puses, liedzot iespēju bērna mātei palikt anonīmai, paredzot atbildību par bērna atstāšanu, bet savukārt tādā veidā nodrošinot bērnam noteiktās tiesības zināt izcelsmi, iespējams, var panākt pretēju rezultātu - abortu skaita pieaugumu, zīdaiṇu mirstības skaita palielināšanos. Vērtējot glābējsilīšu darbību no apskatītā aspekta, secināms, ka bērna tiesības zināt savu izcelsmi pretnostatītas bērna tiesībām uz dzīvību. Tiesības 
uz dzīvību ir pirmatnējas, fundamentālas pamattiesības, ar kurām ir apveltīta ikviena cilvēciska būtne, un bez kuru aizsardzības visas pārējās cilvēktiesības kḷūst mazāk nozīmīgas jeb mazāk efektīvas.[9, 63] Bērna dzīvība ir galvenā pamatvērtība, tāpēc šìs tiesības aizsardzība prevalē pār bērna tiesību zināt savu izcelsmi. Atsaucoties uz klauzulai sniegto skaidrojumu, norādāms, ka glābējsilīšu gadījumā netiek nevajadzīgi pārkāptas bērna tiesības zināt savu izcelsmi, jo iestāžu rīcībā nav ziṇu par bērna izcelsmes vecākiem.

\section{Secinājumi}

Izvērtējot ANO un EP nostāju, veicot ECT un Latvijas tiesu prakses analīzi, autore secina, ka, lai nodrošinātu nepārprotamu bērna tiesību zināt savu izcelsmi izpildi nacionālā līmenī, nepieciešams iekḷaut BTAL 8. pantā trešo daḷu un izteikt to šādā redakcijā: (3) "Bērnam ir tiesības zināt savu izcelsmi likumā noteiktā kārtībā."

Šāda papildinājuma iekḷaušana l̦aus izvairīties no jēdziena "identitāte" nepamatoti sašaurinātas interpretācijas, piemērojot tiesību normas. Papildus nepieciešams veikt grozijjumus speciālajos likumos par adopcijas un medicinniskās apaug̣̦ošanas tiesisko regulējumu, tādējādi panākot taisnīgu līdzsvaru pretēju interešu aizsardzībā. Saskaṇā ar starptautiskajām saistībām, kuras Latvija uzṇēmusies, ir jābūt noteiktam tiesiskam regulējumam, kas ḷauj bērnam realizēt ANO un ECT Konvencijās garantētās tiesības zināt savus izcelsmes vecākus, ja valsts rīcībā tādas ziṇas ir.

\section{Rights of a Child to Know its Origin: Volume and Topical Issues of Concern}

\section{Abstract}

The objective of the article is to analyse problems of legal frameworks of a child's rights to know its origin in case of adoption, baby boxes and medically assisted fecundation, as well as to put forth amendments in the legislation if discrepancy is ascertained between international commitments of a state and regulation in the national legislation of a child's rights to know its origin. Implementation of a child's right to know its origin is analysed, examining the attitude of subjects of international public law - the United Nations and the Council of Europe in supervision of children's legal interests; performing research of regulatory enactments, recommendations and directions, judgements of courts and comparing legal framework of a child's rights to know its origin in the Republic of Latvia.

Keywords: origin, adoption, baby boxes, medically assisted fecundation. 


\section{Literatūra}

1. Administratīvās rajona tiesas 2013. gada 5. aprīla spriedums lietā Nr. A420586212 (A02582-12/21), 10. rindkopa.

2. Administratīvās rajona tiesas 2013. gada 25. aprīla spriedums lietā Nr. A420554312 (A02353-13/36), 12. rindkopa.

3. Administratìvās apgabaltiesas 2013. gada 27. augusta spriedums lietā Nr. A420560012 (AA43-2733-13/10), 4., 6. rindkopa.

4. Eiropas Cilvēktiesību tiesas 1989. gada 7. jūlija spriedums Gaskin vs. The United Kingdom (Nr. 10454/83), \$ 39.

5. Eiropas Cilvēktiesību tiesas 2002. gada 7. februāra spriedums lietā Mikulić vs. Croatia (Nr. 53176/99), $\$ 53$.

6. Eiropas Cilvēktiesību tiesas 2002. gada 5. novembra spriedums lietā Yousef vs. the Netherlands (Nr. 33711/96), \& 59.

7. Eiropas Cilvēktiesību tiesas 2003. gada 13. februāra spriedums lietā Odièvre vs. France (Nr. 42326/98), $\mathbb{} 33$.

8. Mileiko, I. Biodrošîbas aspektu izvērtējums mākslīgās apaugḷošanas gadījumā. Priekšizpētes ziṇojums, Rīga, 2010, [skatīts 28.10.2013.]. Iegūts no: http://www.biodrosiba.lu.lv/fileadmin/ user_upload/lu_portal/projekti/biodrosiba/IMileiko_Maksliga_apauglosana.pdf

9. Bertrand, G. R. The right to life in International Law. Netherland: Martinus Nijhoff Publishers, 1985, p. 63.

10. Concluding Observations of the Committee on the Rights of the Child, France, U.N. Doc. CRC/C/15/Add.240, 2004, p. 23, 24, [skatīts 18.08.2013.]. Iegūts no: http://korczak.fr/partenaires/ong/cdre_recomm_040604.pdf

11. Concluding Observations of the Committee on the Rights of the Child. United Kingdom of Great Britain and Northern Ireland, U.N. Doc. CRC/C/15/Add.188, 2002, 31, 32 p., [skatits 18.08.2013.]. Iegūts no: http://www2.ohchr.org/english/bodies/crc/docs/AdvanceVersions/ CRC.C.GBR.CO.4.pdf

12. Council of Europe. Draft Recommendation on the rights and legal status of children and parental responsibilities. Strasbourg, 8 April 2011, CJ-FA-GT3, 2010, art. 4 (2).

13. Implementation handbook for the Convention on the rights of the child. Rachel Hodgkin and Peter Newell, Unicef, 2002, p. 117.

14. O’ Donovan, K. A. Right to know ones parentage? International Journal of Law, Policy and the Family, Vol. 2, 1988, p. 28.

15. Kothari, J. The child's right to identity: Do adopted children have the right to know their parentage?, [skatìts 10.08.2013.]. Iegūts no: http://www.cry.org/resources/pdf/NCRRF/NCRRF_ ReportBy_Jayna.pdf

16. Randeep, R. Spreadof 'baby boxes' in Europe alarms United Nations. The Guardian, 10.06.2012., [skatīts 18.08.2013.]. Iegūts no: http://www.theguardian.com/world/2012/jun/10/ unitednations-europe-news? INTCMP=SRCH

17. Stoll, J. Surrogacy Arrangements and Legal Parenthood. Swedish Lawin a Comparative Context. Uppsala: Uppsala Universitet, 2013, p. 39.

18. Аикова, И. А. Актуальнье проблемь донорства половых клеток. Право и жизнь, № 136, 2009, [skatīts 03.11.2013.]. Iegūts no: http://www.law-n-life.ru/arch/n136.aspx 